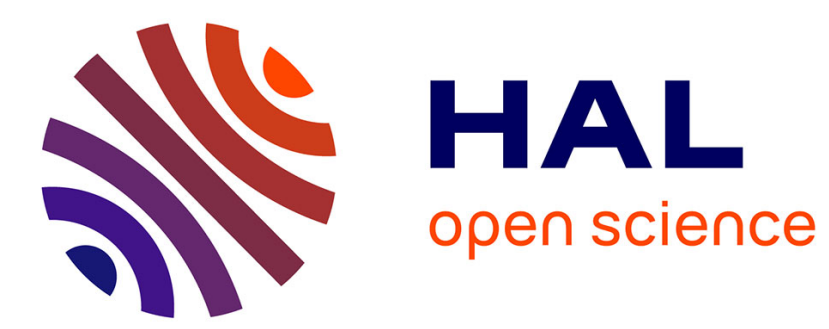

\title{
Environmental governance for all
}

Eduardo S Brondizio, François-Michel Le Tourneau

\section{To cite this version:}

Eduardo S Brondizio, François-Michel Le Tourneau. Environmental governance for all. Science, 2016, 352 (6291), pp.1272-1273. 10.1126/science.aaf5122 . halshs-01338301

\section{HAL Id: halshs-01338301 https://shs.hal.science/halshs-01338301}

Submitted on 19 Sep 2016

HAL is a multi-disciplinary open access archive for the deposit and dissemination of scientific research documents, whether they are published or not. The documents may come from teaching and research institutions in France or abroad, or from public or private research centers.
L'archive ouverte pluridisciplinaire HAL, est destinée au dépôt et à la diffusion de documents scientifiques de niveau recherche, publiés ou non, émanant des établissements d'enseignement et de recherche français ou étrangers, des laboratoires publics ou privés. 


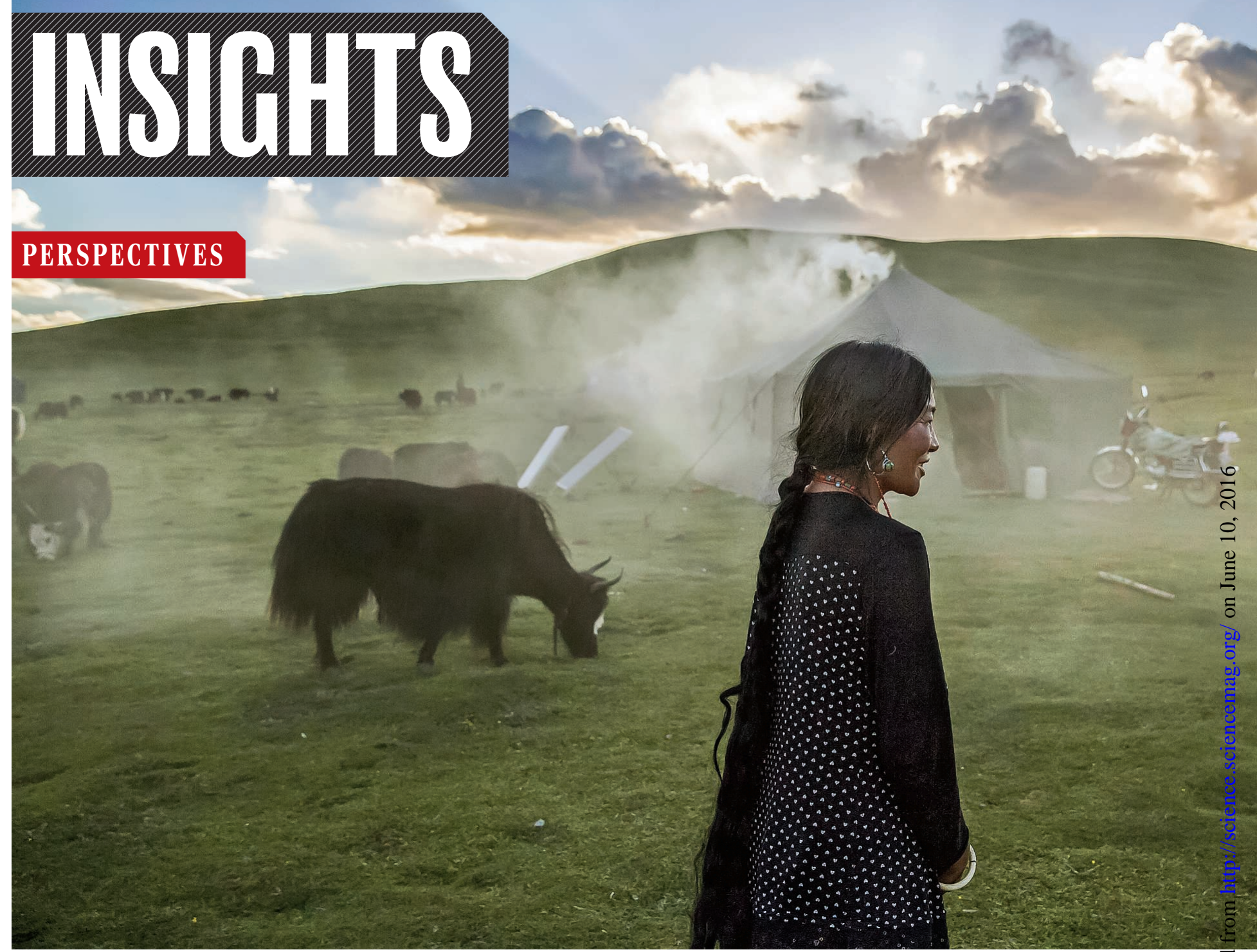

ENVIRONMENT

\section{Environmental governance for all}

Involving local and indigenous populations is key to effective environmental governance

\section{By Eduardo S. Brondizio ${ }^{1,3}$ and}

Francois-Michel Le Tourneau ${ }^{2,3}$

$\mathrm{n}$ a world increasingly thought of as overpopulated, sparsely populated spaces remain a dominant feature: $\sim 57 \%$ of Asia, $\sim 81 \%$ of North America, and $\sim 94 \%$ of Australia have population densities below 1 person per square kilometer, equivalent to the population density of most of the Sahara desert (1). These vast, sparsely populated landscapes include rural settlements, towns, agricultural spaces, extractive economies, indigenous lands, and conservation areas. They are crucial for climate change adaptation and mitigation, from carbon se- questration to provisioning of water, food, and energy to cities. Yet governmental and nongovernmental initiatives tend to mostly pay lip service to the diverse views and needs of their populations. Without more inclusive governance, attempts to mitigate and adapt to climate change and conserve ecosystems will be compromised.

To be politically legitimate and longlasting, incentives and regulations for better conservation and climate change mitigation must engage with the claims, rights, and knowledge of local and indigenous populations (2), which may be spread over immense and distant territories. The importance of local and indigenous populations in governing ecosystems and biodiversity and in meeting global climate change mitigation goals has been firmly asserted in international conventions such as the Convention on Biological Diversity [CBD article $8(\mathrm{j})$ ], the Intergovernmental Science-Policy Platform on Biodiversity and Ecosystem Services (3), and in agreements and commitments made at the COP21 climate meeting in Paris in 2015. How-

${ }^{1}$ Department of Anthropology, Center for the Analysis of SocialEcological Landscapes, and Ostrom Workshop in Political Theory and Policy Analysis, Indiana University, Bloomington, IN 47405, USA. ${ }^{2}$ Center for Research and Documentation on the Americas, Paris 3 Sorbonne Nouvelle University and CNRS, 75007 Paris, France. ${ }^{3}$ Institut des Ameriques, 92170 Vanves, France. Email: ebrondiz@indiana.edu 
resources are usually transformed in distant metropolises, where value aggregation takes place, leaving behind social costs and often insolvent public administrations. Having limited access to social services and infrastructure and lacking employment opportunities, young generations migrate and circulate in search of opportunities in expanding regional urban centers. Yet sparsely populated areas are increasingly targeted to meet national and global conservation and climate mitigation goals $(7,8)$, and local and indigenous populations, many of which are poor (9), are expected to take on growing responsibilities as environmental stewards.

For instance, to meet the global conservation goals specified in the CBD's Aichi Target 11 , an increase of $\sim 3 \%$ in total terrestrial and inland water protected areas is called for during the next 4 years, representing more than 3 million $\mathrm{km}^{2}(8)$. Most of these areas will be in regions of Africa, Latin America, and Asia that local and indigenous populations depend on for resources, agriculture, and husbandry. This expansion implies strict restrictions on, or abandonment of, land-use systems that have in many cases coevolved and contributed to the long-term health and diversity of regional ecosystems.

Examples of questionable environmental and social outcomes of top-down conservation expansion policies abound. For example, since the 1990 s, the implementation of grassland management policies imposed on 1.5 million $\mathrm{km}^{2}$ of the Tibetan plateau by the Chinese government-including largescale conservation areas, restriction on nomadic lifestyle and resettlements, fencing grasslands, and limiting herd size-has threatened the livelihood of millions of pastoralists whose grazing systems have coevolved with grassland species. Compounded by climate change, infrastructure development, and pollution, this type of centralized "one size fits all" approach to environmental management also leads to mixed and concerning environmental outcomes, including the possibility of speeding up the release of grassland carbon stocks and potentially threatening the water supply of Asia's largest rivers, upon which 1.6 billion people depend (10).

As demands for both commodities and conservation grow, so do mismatches in land use, property regimes, and governance arrangements, undermining the sustainable governance of landscapes (11, 12). For instance, although indigenous, sustainable-use, and conservation areas have expanded to cover more than $40 \%$ of the Brazilian Amazon today, they are increasingly surrounded and undermined by large-scale agriculture and ranching, logging, and energy and mining extraction. Although effective in buffer- ing deforestation, these areas are becoming islands of cultural and biological diversity, undermining their social and environmental effectiveness (13). New approaches are needed to reconcile conservation goals, expanding resource economies, and the role of local and indigenous populations in landscape governance $(8,11,12)$.

To be effective, environmental governance solutions must involve local and indigenous populations (2), and national goals and international commitments must be reconciled with local and indigenous needs and cultural perspectives, as varied as they may be. Approaches and programs that bridge diverse constituencies in resource governance are emerging in many parts of the world, including rural regional governance in the United States, multifunctional landscapes in different parts of Europe, cities protecting common watersheds in the Andes, and comanagement systems in the tropics.

For instance, collaborative efforts between scientists, policy-makers, and locals are pointing to new ways of conceiving and implementing programs that combine poverty alleviation and conservation across large pastoral ecosystems of East Africa (14). Large international networks, such as the Global Landscape Forum led by the Center for International Forestry Research, are also bringing together a wide range of stakeholders to share ideas, propose solutions, and make commitments for the inclusive management of landscapes. Such efforts, if connected with national policies and international mitigation programs, can help to meet climate change mitigation and conservation objectives and move us closer to meeting the challenges of the United Nations' Sustainable Development Goals.

\section{REFERENCES AND NOTES}

1. LandScan data platform, Oak Ridge National Laboratory; web.ornl.gov/sci/landscan/landscan_data_avail.shtml.

2. J. Mistry, A. Berardi, Science 352,1274 (2016).

3. S. Díaz etal.,Curr. Opin. Environ. Sustain. 14,1 (2015).

4. E.C. Ellis etal.,Proc. Natl.Acad. Sci. U.S.A.110,7978 (2013).

5. T. Sikor, Ed., The Justices and Injustices of Ecosystem Services (Routledge, London, 2013).

6. L. Calvet-Mir et al., Curr. Opin. Environ. Sustain. 14, 150 (2015)

7. J. Fairhead et al., J. Peasant Studies 39, 237 (2012).

8. S. H. M. Butchartet al.,Conserv. Lett. 8,329 (2015).

9. D. Brockington, D. Wilkie, Philos. Trans. R. Soc. B 370 , 20140271(2015)

10. J. Qiu, Nature 529,142 (2016)

11. F.M. Pouzols etal., Nature 516,383 (2014).

12. A. K. Duraiappah et al., Curr. Opin. Environ. Sustain. 7,94 (2013).

13. F.-M. Le Tourneau, Curr. Opin. Environ. Sustain. 14, 213 (2015).

14. R. Reidetal.,Proc. Natl. Acad. Sci. U.S.A. 113,4579 (2016).

\section{ACKNOWLEDGMENTS}

F.-M.L.T. thanks the Ostrom Workshop visiting scholar program and the CNRS international mobility program. E.S.B. thanks the RIHN (Kyoto) invited scholar program.

10.1126/science.aaf5122
Sparsely populated areas often receive limited investments in human capital and infrastructure. Locally produced and extracted 


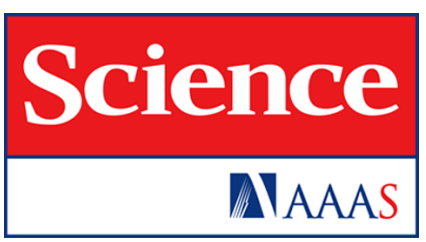

Environmental governance for all

Eduardo S. Brondizio and Francois-Michel Le Tourneau (June 9, 2016)

Science 352 (6291), 1272-1273. [doi: 10.1126/science.aaf5122]

Editor's Summary

This copy is for your personal, non-commercial use only.

Article Tools Visit the online version of this article to access the personalization and article tools:

http://science.sciencemag.org/content/352/6291/1272

Permissions Obtain information about reproducing this article:

http://www.sciencemag.org/about/permissions.dtl

Science (print ISSN 0036-8075; online ISSN 1095-9203) is published weekly, except the last week in December, by the American Association for the Advancement of Science, 1200 New York Avenue NW, Washington, DC 20005. Copyright 2016 by the American Association for the Advancement of Science; all rights reserved. The title Science is a registered trademark of AAAS. 